\title{
Otonom Araçların Benimsenmesi ve Güvenlik Algılarının İncelenmesi
}

\author{
Gözde Bakioğlu ${ }^{1 *}$, Ali Osman Atahan ${ }^{2}$ \\ 1* İstanbul Teknik Üniversitesi, İnşaat Fakültesi, İnşaat Mühendisliği Bölümü, İstanbul, Türkiye, (ORCID: 0000-0003-3754-2631), bakioglugo@itu.edu.tr \\ 2 İstanbul Teknik Üniversitesi, İnşaat Fakültesi, İnşaat Mühendisliği Bölümü, İstanbul, Türkiye (ORCID: 0000-0002-4800-4022), atahana@itu.edu.tr
}

(International Conference on Design, Research and Development (RDCONF) 2021 - 15-18 December 2021)

(DOI: 10.31590/ejosat.1039725)

ATIF/REFERENCE: Bakioğlu, G., Atahan, A. O. (2021). Otonom Araçların Benimsenmesi ve Güvenlik Algılarının İncelenmesi. Avrupa Bilim ve Teknoloji Dergisi, (32), 633-639.

$\ddot{\mathbf{O} z}$

Çevresel algılama özelliklerine sahip olan seviye "3" otonom araçların çok yakın bir zamanda tüm araçlarda görülmesi beklenirken, sürücünün sürüş görevini ortadan kaldıran seviye "5" otonom araçların ise on sene içerisinde ticarileştirileceği düşünülmektedir. Seviye "5" otonom araçların sürdürülebilir kentsel hareketliliği arttıracağı ve insan kaynaklı hataları azaltıp trafik kazalarını azaltması beklenmektedir. Bununla birlikte bu teknolojinin çeşitli güvenlik sorunlarını da beraberinde getireceği düşünülmektedir. Bu noktada yeni teknoloji ürünü olacak bu araçların benimsenip benimsenmeyeceği önemli bir konudur. Bu çalışmada otonom araçların benimsenmesini etkileyecek faktörler incelenecek olup, aynı zamanda kişilerin bu araçlara karşı güvenlik algıları araştırılacaktır. Araştırma sonucu çıkacak bulguların, otonom araçlar ile ilgili karar vericiler ve politika belirleyiciler için yararlı olması beklenmektedir.

\section{Investigating the Safety Perception and Adoption of Autonomous Vehicle}

\begin{abstract}
With the advancement of technology, transportation systems have started to transform the way of digitalization. Level 3 autonomous vehicle having the capability of environmental detection will nearly be available for all vehicles soon. Level 5 self-driving vehicles will probably be commercialized within 10 years, and these vehicles are expected to enhance the sustainable urban mobility and decrease the traffic crashes caused by human error. However, new technology may bring some safety and security issues. In this regard, adoption of autonomous vehicle will be of decisive importance. This study examines the factors affecting the adoption of autonomous vehicle, and safety and security perceptions towards those vehicles. The findings of this study will be conducive for decision-makers and policy-makers.
\end{abstract}

Keywords: Autonomous vehicle, Adoption of technology, Safety Concern, Crash.

\footnotetext{
* Sorumlu Yazar: İstanbul Teknik Üniversitesi, İnşaat Fakültesi, İnşaat Mühendisliği Bölümü, İstanbul, Türkiye, ORCID: 0000-0003-3754-2631, bakioglugo@itu.edu.tr
} 


\section{Giriş}

Araç otomasyon teknolojilerinin gelişmesi ile birlikte ulaşım sistemleri tekrardan şekillenmektedir. Gelecek ulaşım sistemlerinin daha akıllı ve daha otomatik sistemleri içermesi beklenmektedir. Otonom araçlar, sürdürülebilir kentsel hareketlilik sistemlerini gelecek yillarda temelden değiştirecektir. Otonom araçların engelli ve yaşlı olan bireyler için hareketliliği arttırması, kazaları azaltması, yayalar ve bisiklet sürücüleri için güvenliği arttırması, trafiği ve egzoz gazı emisyonunu azaltması beklenmektedir (Howard ve Dai, 2014).

Kör noktaları yakalamak gibi yüksek seviyede algılama özellikleri, kısa reaksiyon süresi, hassas direksiyon kontrolü gibi güçlü karar verme özellikleri sebebi ile sürücüsüz araçların sürücü ile hareket eden araçlardan daha iyi performans göstereceği varsayılmaktadır. Sürücülerin yorgunluk, dikkat dağınıklığı, yüksek hız yapma eğilimi ve uykusuzluk gibi insana dair hataların sonucunda meydana gelen trafik kazalarının otonom araçlar ile giderileceği düşünülmektedir (Fagnant ve Kockelman, 2015).

Otomotiv Mühendisleri Topluluğu (SAE), Milli Karayolları Trafik Güvenliği Yönetimi (NHTSA) tarafından benimsenmiş olan altı adet otomasyon seviyesi tanımlamıştır (SAE, 2018). Günümüzde çeşitli sürüş destek sistemleri birçok farklı araçlarda mevcuttur. Seviye "1" ve "2" araçları dünya genelinde neredeyse her yerde mevcut iken, seviye "3" araçları ise endüstrileşmiş bazı ülkelerde mevcuttur. Otomatik acil fren sistemleri ve önden çarpma uyarı sistemlerinin 2022 yılı içerisinde tüm araçlarda bulunacağ 1 tahmin edilmektedir. Seviye "5" araçlarının ise 2030 yılına kadar Avrupa ülkelerinde ticarileştirilmesi beklenmektedir. Şekil 1'de otonom sürüş seviyelerine (SAE) ait özet bilgiler gösterilmektedir.

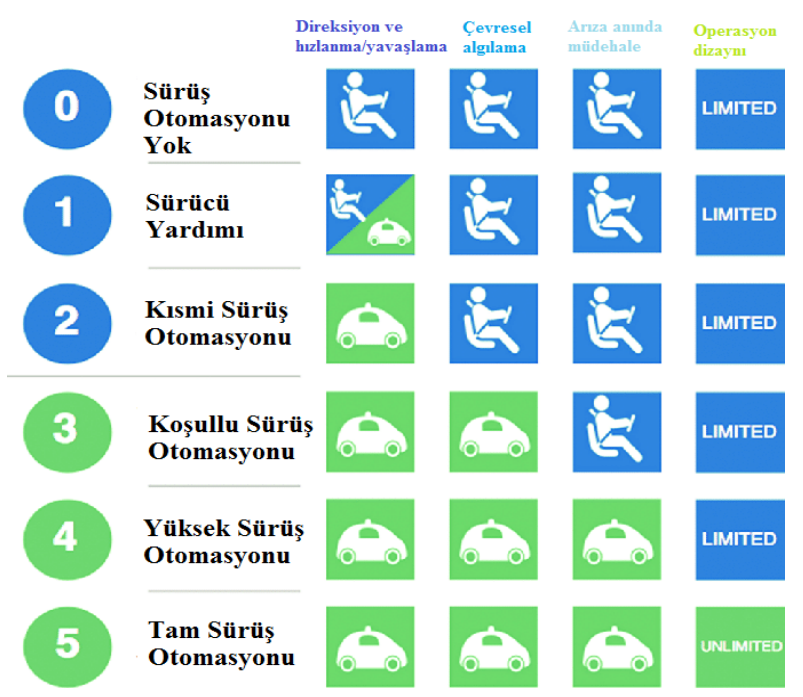

Şekil 1. Otonom Sürüş Seviyeleri (SAE, 2018)

Çevresel algılama özelliğine sahip olan araçlar, önünde bulunan ve hızı daha yavaş olan araçları sollamak ve sollarken hızını arttırmak gibi kararları verebilirler. Seviye "4" ve seviye "5" araçlarda, sistem tarafindan bir hata olması durumunda aracın kendi kendine bu hataya müdahale ettiği gözlemlenmektedir. Seviye "4" araçlar, yasal sorumluluklar ve mevzuatlar belirleninceye kadar, kısıtlı bir hız miktarına çıkabilecek ve sınırlı bir alanda çalışabileceklerdir.
Bununla birlikte teknolojik gelişmelerin bazı potansiyel güvenlik sorunlarını beraberinde getireceği düşünülmektedir. Otonom araçlara yapılabilecek siber saldırı riski, çeşitli trafik kazalarına sebep olabilir. Yolcuların konumları ve varış noktaları gibi kişisel bilgilerini akıllı ulaşım sistemleri ile paylaşmaları da önemli bir güvenlik kaygısı olarak görülmektedir. Siber saldırılar kişisel bilgileri açığa çıartabilir ve kazalara yol açabilir. Bunlara ek olarak yeni teknolojiye güvensizlik duyulması, yeni teknoloji maliyetlerinin yüksek olması, sürücü ile ilgili iş alanları kayıpları ve otonom araçlarla ilgili yasal sorumlulukların tam olarak bilinmemesi, otonom araçların dezavantajları arasında yer almaktadır (Schoettle ve Sivak, 2014).

Tüm bunlar düşünüldüğünde sürücüsüz araçların benimsenmesi yönünde çeşitli faktörlerin olduğu ve bu teknolojiye karşı bazı güvensizlikler yaşandığ 1 ortadadır. $\mathrm{Bu}$ çalışmanın amacı ise bu faktörleri ortaya çıkartmak ve kişilerin otonom araçlara karşı güven kaygılarını tespit etmektir. Aynı zamanda sürücüsüz araçların güvenliğine değinilirken bu araçlarla ilgili kazaları incelemek, araçların uygulamada ne gibi problemlerle karşılaştığının görülmesi bakımından da yararlı olacaktır.

$\mathrm{Bu}$ makalenin ikinci bölümünde otonom araçların benimsenmesini etkileyen faktörler incelenirken, üçüncü bölümünde yol güvenliği ve otonom araçların güvenlik algılarına değinilmektedir. Dördüncü bölümde otonom araçlara ilişkin kaza analizleri yapılmakta ve beşinci bölümde bulgular tartışılmaktadır.

\section{Otonom Araçlarm Benimsenmesini Etkileyen Faktörler}

Yeni teknolojiye aşina olamama durumu ve teknolojiye ait çeșitli işletimsel sorunların ortaya çıkma ihtimali, kullanıcıların bu yeni teknoloji ürünü olacak araçları benimseyip benimsemeyecekleri önemli bir araştırma konusu olmuştur. Bazı çalışmalarda "teknoloji" terimi, insanlar tarafindan felaket ve tehlike getirecek durumları içeren bir kavram olarak ortaya çıkmaktadır (Brell ve diğ., 2018).

Siber saldırı, potansiyel sistem bozuklukları gibi kritik sorunlar insanlarda teknolojik araçlara karşı önyargı oluşturabilir. Böylece kontrolün tamamen teknolojik araçta olup sürücüde olmaması, kullanıcıları otonom araçları tercih edip etmeyecekleri yönünde düşündürmektedir. Otonom araçların piyasaya sürülmeden önce iyice incelenmesi ve bu araçların kabullenilmesine etki edecek faktörlerin araştırılarak çıkabilecek tüm sorunlara çözüm önerileri getirilmesi gerekmektedir.

Sürücüsüz araçların potansiyel kullanımını ve bu araçların benimsenmesini etkileyen faktörler ve çeşitli alt parametreler Şekil 2'de gösterilmiştir. Şekil 2'de faktörlerin ve alt parametrelerin birbirleri ile bağlantıları sergilenmektedir. 


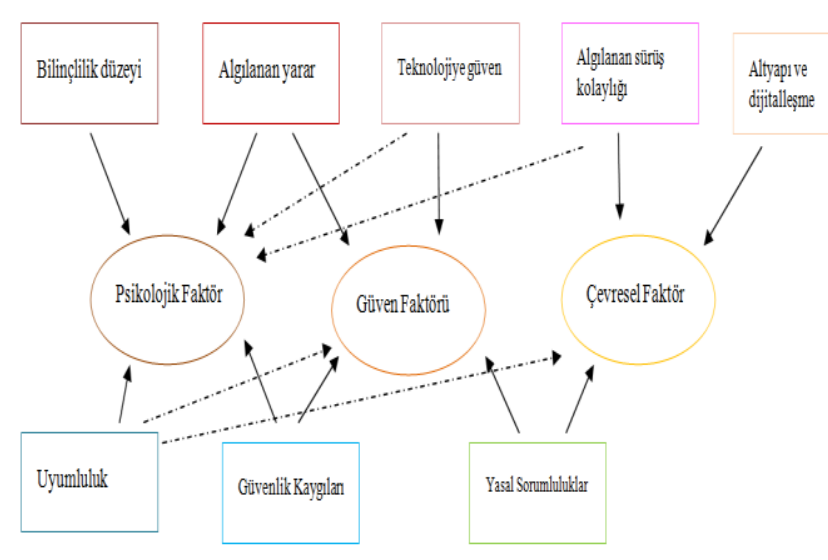

Şekil 2. Otonom araçların benimsenmesini etkileyen faktörler

Yapılan araştırmalar sonucunda otonom araçların kabullenilmesi yönünde etkisi olabilecek faktörleri üç ayrı grupta kümelendirebiliriz. Otonom araçlara karşı bilinçlilik düzeyi, yeni teknolojiye uyum sağlayabilme yetisi, bu teknolojinin getirebileceği yeniliklerin ve yararların algılanabilme düzeyi psikolojik faktörleri oluşturur. Kişilerin kendilerini psikolojik olarak otonom araç kullanımına hazırlayabilmeleri için bu araçlar ile ilgili belirli bir bilinç düzeyine erişmeleri ve bu teknolojinin getireceği yeniliklere açık olmaları gerekmektedir. Sanbonmatsu ve diğerleri (2018) otonom araçlarla ilgili bilgisi olan kişilerin, bu araçların kullanımını benimsemelerinin daha kolay olduğunu belirtmiştir. Yapılan farklı çalışmalarda bireylerin yaşam tarzları ve kişiliklerinin, otonom araçları yararlı ve zararlı olarak algılamasında etkili olduğu sonucuna ulaşılmıştır (Payre ve diğ., 2014).

Literatürde bulunan birçok çalışmada güvenlik faktörü otonom araçların kabullenilmesi yönünde en önemli etken olarak gösterilmektedir (Casley ve diğ., 2013; Kyriakidis ve diğ., 2015; Bakioglu ve Atahan, 2020). Yeni teknolojiye güvenmek ve otonom araçlarla ilgili çeşitli kaygılar, güvenlik faktörünü oluşturan alt parametrelerdir. Casley ve diğerlerinin (2013) yaptığı bir anket çalışmasında kişilere otonom araçla ile ilgili kaygıları sorulmuş ve cevap veren kişilerin beşte dördünün güvenlik kaygılarını öncelediği gözlemlenmiştir. Kyriakidis ve diğerleri (2015), otonom araçlara karşı güvenlik kaygılarını araştırmak için kişilerin kendilerini kontrol edemedikleri bir araç içerisinde ve etrafı çeşitli otonom araçlarla çevrili iken rahat hissedip hissetmediklerini içeren bir çalışma düzenlemiştir. Kendilerini rahat hissetmeyen kişilerde otonom araçlara karşı güvenlik ile ilgili kaygılar olduğunu tespit etmiştir. Bakioğlu ve Atahan (2020)'ın yaptığı çalışmada çok kriterli karar verme yaklaşımları kullanılarak sürücüsüz araçların benimsenmesini etkileyen faktörler araştırılmış ve güvenlik kaygıları ilk sırada yer almıştır.

Teknolojiye güvenmek ve teknoloji ürünü araçlara binmek kişilerin demografik özelliklerine göre değişiklik göstermektedir. Power ve diğerlerinin (2012) yaptığ 1 çalışmada erkeklerin kadınlara göre teknolojik araçları daha çok benimsediği ve tam sürüş otomasyon seviyesine geçmek için ücret ödemeye daha çok yatkın oldukları bulunmuştur. Shin ve diğerleri (2015) ise yaşı ileri olan kişilerin genç olanlara göre yeni teknolojiye daha az güvendiğini ve teknolojik araçları daha az benimsediğini ortaya çıkartmıştır.
Sürücüsüz araçların benimsenmesini etkileyen bir diğer faktör çevresel faktördür. Yasal sorumluluklar, algılanan sürüş kolaylığı, altyap1 ve dijitalleşme alt parametreler olarak sayılabilir. Otonom araçların kaza yapması sonrasında hatanın hangi tarafta aranacağı konusunun henüz belirli olmaması sorun teşkil etmektedir. Yasal olarak kazadan sorumlu taraf araç-üretim yetkilileri mi, yoksa aracın içindeki yolcular mı olacağının belirsizliği sebebi ile kişilerin otonom araçlara karşı kaygıları oluşmakta ve bu durum sürücüsüz araçların kabulünü negatif yönde etkilemektedir. Otonom araçların hareket edebilmeleri için elektronik altyapının oluşturulması ve ulaşımın dijitalleştirilmesi kişiler üzerinde çeşitli kaygılar oluşturabilmektedir. Bunların yanı sıra algılanan sürüş kolaylığı ve kişilerin sürüş şekilleri, otonom araçları kabullenme açısından öneme sahiptir. Howard ve Dai (2014) yolculuklarının çoğunu tek başına yapan sürücülerin otonom araçları satın almaya daha az yatkın oldukları sonucuna varmıştır.

Alt parametrelerin diğer faktörler ile ilişkilerine baktığımızda, uyumluluk parametresinin üç faktör içinde ortak bir kavram olduğunu görebiliriz. Otonom araçlara olan uyum psikolojik faktör ile ilişkilendirilirken, yeni teknolojik bir aracı kullanmaya uyum göstermek ve bu durumdan kaygılanmamak güven faktörü ile bağdaştırılabilir. Ulaşımın dijitalleşmesine uyum sağlamak ve bu durumu benimsemek çevresel değişkenlere uyum sağlandığını gösterir. Otonom araçlara karşı yarar algısı ile güvenlik faktörü ve yasal sorumluluk alt parametresi ile çevresel faktörün yanı sıra güven faktörü ilișkilendirilmiştir. Choi ve Ji (2015) algılanan kullanışlılık ve yararın otonom araçlara güveni direkt olarak etkilediğini bulmuştur. Howard ve Dai (2014) ise otonom araçların yasal sorumluluk ve yükümlülükler sorununun bu araçlara güvenmek konusunda önemli bir etkisi olduğunu ortaya çıkartmıştır.

\section{Yol güvenliği ve Otonom Araçların Güvenlik Algıları}

Otomotiv güvenliği kompleks bir sorun olup; araç, altyap1, çevre ve insan faktörlerine bağlıdır (Dixit ve diğ., 2016). Trafik kazalarının sebeplerine bakıldığında insan faktörünün daha çok öne çıktığı görülmektedir. Yapılan araştırmalarda \%80 oranında trafik kazalarının insan kaynaklı olduğu görülürken, kazalarda meydana gelen ölümlerin $\% 75$ 'inin erkek olduğu, yarısından çoğunun da 15-44 yaş aralığındaki kişilerden oluştuğu tespit edilmiştir (WHO, 2020).

Meydana gelen kazaların çoğunluğunun insan sebepli olmas1, insan müdahalesini ortadan kaldıracak olan sürücüsüz araçlara olan ilgiyi ve merakı arttırmaktadır. Otonom araçların bu bağlamda yorgunluk, dikkatsizlik, uykusuzluk ve aşırı hız gibi insana ait sebeplerden kaynaklı trafik kazalarını azaltıp, trafik akışını optimize ederek trafik güvenliğini arttıracağı düşünülmektedir. Dixit ve diğerlerinin (2016) yaptığı çalışmada insanların otonom araçlara geçmekte hevesli olmasının sebebinin yol güvenliği olduğunu söylemiştir. Seviye "5" otonom araçlarla ilgili az sayıda trafik kazası rapor edilirken, geleneksel araçlarla ilgili günlük çok daha fazla sayıda kaza rapor edilmesi bu düşünceyi desteklemiştir.

Bununla birlikte literatürde otonom araçlar ile ilgili birçok kayg1 ve endişeler yer almaktadır. Avustralya'da yapılan bir anket çalışmasında katılımcıların sadece $\% 45$ 'i otonom araçların trafik kazalarını, gaz emisyonunu ve yol stresini azaltacağını söylemiştir (Pettigrew ve diğ., 2019). Bu durum kişilerin otonom 
araçlara karşı bir güven eksikliği duyduklarını açıkça göstermektedir. $\mathrm{Bu}$ düşüncelerde görsel basın ve sosyal medyanın da etkileri bulunabilir. Otonom araçların yararlarından çok yapılan kazaların gündeme gelmesi, kişiler üzerinde otonom araçlara karşı önyargı oluşmasına sebep olmaktadır (Dixit ve diğ., 2016).

On sene içerisinde araç piyasasında yer alması beklenen otonom araçlara karşı oluşacak güven algılarının tespit edilmesi, özellikle araçların üretimi ve satışı esnasında araç imalatçıları ve politika belirleyicilere yol göstermesi bakımından önem taşımaktadır. Otonom araçlara karşı kişilerin güvenlik algılarını içeren bilgiler ve bilgilerin kaynakları Tablo 1'de gösterilmiştir. Şekil 3'te ise otonom araç güvenlik algılarını etkileyen faktörler vurgulanmaktadir.

Tablo 1. Otonom araç güvenlik algıları

\begin{tabular}{|c|c|}
\hline Otonom araç güvenlik algıları & Referanslar \\
\hline Güvenlik kaygıları & $\begin{array}{l}\text { Casley ve diğ. (2013), Howard } \\
\text { ve Dai (2014), Gkartzonikas } \\
\text { ve Gkritza (2019) }\end{array}$ \\
\hline $\begin{array}{l}\text { Yasal yükümlülükler } \quad \text { ve } \\
\text { sorumluluklar }\end{array}$ & $\begin{array}{l}\text { Casley ve diğ. (2013), Begg } \\
\text { (2014), }\end{array}$ \\
\hline Etik ve ahlak kavramları & $\begin{array}{l}\text { Bansal ve diğ. (2016), Chen ve } \\
\text { diğ. (2017) }\end{array}$ \\
\hline $\begin{array}{l}\text { Siber güvenlik ve bilgi gizliliği } \\
\text { problemleri, Araç sisteminin } \\
\text { heklenme olasılığ }\end{array}$ & $\begin{array}{ll}\text { Begg } & (2014), \text { Schoettle ve } \\
\text { Sivak } & (2014), \text { Noy ve diğ., } \\
2018 & \end{array}$ \\
\hline $\begin{array}{lll}\text { Doğru } & \text { konumlama } & \text { ve } \\
\text { haritalama } & & \\
\end{array}$ & Brell ve diğ. (2018) \\
\hline Çevresel kaygılar & $\begin{array}{l}\text { Bansal ve diğ. (2016), Casley } \\
\text { ve diğ. (2013), }\end{array}$ \\
\hline $\begin{array}{l}\text { İletişim sistemleri, Araç-araç, } \\
\text { araç-altyap1, } \\
\text { iletişimleri }\end{array}$ & $\begin{array}{lrrr}\text { Bansal ve } & \text { diğ. } & (2016), \\
\text { Gkartzonikas } & \text { ve } & \text { Gkritza } \\
(2019) & & \\
\end{array}$ \\
\hline $\begin{array}{l}\text { Yüksek fiyat beklentisi ve Satın } \\
\text { alınabilirlik kaygıları }\end{array}$ & $\begin{array}{l}\text { Casley ve diğ. (2013), } \\
\text { Shabanpour ve diğ. }(2018)\end{array}$ \\
\hline Araç ve sistem bozuklukları & $\begin{array}{l}\text { Bansal ve diğ. (2016), } \\
\text { Schoettle ve Sivak (2014) }\end{array}$ \\
\hline $\begin{array}{llr}\text { Otonom } & & \text { araçların } \\
\text { benimsenmesi } & \text { ve } & \text { kişilerin } \\
\text { reaksiyonları } & & \end{array}$ & $\begin{array}{l}\text { Fagnant ve Kockelman (2015), } \\
\text { Kyriakidis ve diğ. (2015), } \\
\text { Sanbonmatsu ve diğ. (2018) }\end{array}$ \\
\hline $\begin{array}{l}\text { Farklı trafik koşullarında aracın } \\
\text { performansı ile ilgili kaygılar }\end{array}$ & Shabanpour ve diğ. (2018), \\
\hline Kontrol kaybı korkuları & $\begin{array}{l}\text { König ve Neumayr (2017) } \\
\text { Payre ve diğ. (2014) }\end{array}$ \\
\hline $\begin{array}{lllll}\text { Dijital altyapı ve özel şerit } \\
\text { tahsisi }\end{array}$ & Shabanpour ve diğg. (2018) \\
\hline
\end{tabular}

5000 katılımcı ile gerçekleştirilmiş olan bir çalışmada kişilerin otonom araçlara karşı güven algıları araştırılmıştır. Araştırma sonucunda otonom araçların sistem güvenliği ile ilgili problemler ve kaza durumunda yasal yükümlülüklerin belirsizliği kaygılarının, insanlarda güven kaybına sebep olduğu anlaşılmıştır. Yasal sorumluluk ve teknoloji faktörlerinin halen belirsizliğini koruması, araç kullanıcılarını otonom araçları kabul etme yönünde negatif olarak etkilemektedir (Begg, 2014). Siber saldırı riskleri, aracın yazılım ve donanımına saldırı ihtimalleri ve bilgi güvenliğinin korunamaması ile ilgili korkular, birçok

e-ISSN: 2148-2683 çalışmada en büyük güvenlik kaygısı olarak bulunmuştur (Noy ve diğ., 2018; Bakioğlu ve Atahan, 2021). Teknoloji faktörünün içerisine, otonom araçların yazılım ve donanımının yanı sıra araçların malzemesi ve sistemini de dâhil edebiliriz. Bansal ve diğerlerinin (2016) yaptığı çalışmada sistem bozuklukları ve sensörlerin bozulması gibi araca ait parçaların çalışmaması ihtimali kişilerde büyük kaygılar oluşturmaktadır. Araçların, araçlarla ve diğer her şey ile iletişimini sağlayan sensörlerde aksaklık olması durumunda veya aracın GPS sisteminde oluşacak problemlerden dolayı yanlış haritalama ile aracın doğru konumunu bulamaması durumunda ne olacağı henüz net değildir. $\mathrm{Bu}$ durum otonom araçlara karşı güvenlik kaygılarını arttırmaktadır.

Schoettle ve Sivak (2014) otonom araçların siber saldırıya uğramasının, aracın yazılım ve donanımsal hatalarının ve aracın bir parçasında oluşabilecek bozuklukların kişiler üzerinde negatif güvenlik algısı oluşturacağını düşünmektedir. Sürücüsüz araçlar kişilerin konumlarını, seyahatlerine başlangıç ve bitiş noktalarını gerçek zamanlı olarak kaydedecektir. Bilgi güvenliğinin sağlanamaması ve seyahate dair bilgilerin açığa çıkması endişesi araç kullanıcılarını endişelendirmektedir.

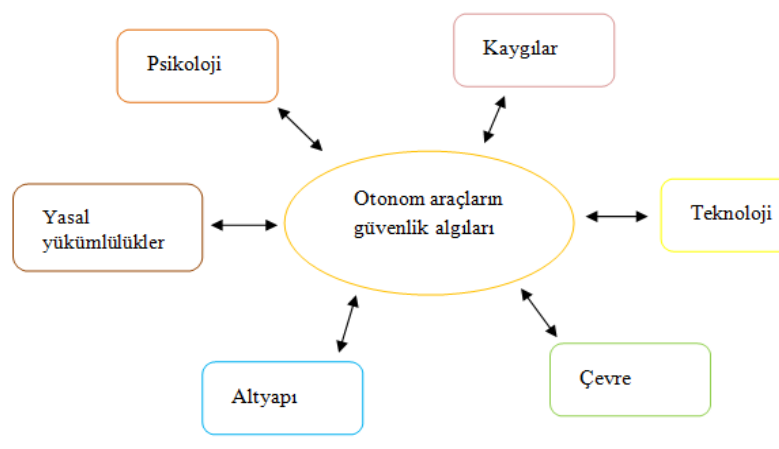

Şekil 3. Otonom araç güvenlik algılarını etkileyen faktörler

Psikoloji etkeni, kişilerin otonom araçlara karşı güvenlik algılarını etkilemektedir. Araç kontrolünün kişide olmaması ve gerektiği yerde müdahale edememesi araç kullanıcılarında çeşitli kaygılara sebep olmaktadır (König ve Neumayr, 2017). Davranışsal tutumlara baktığımızda kişilerin, teknolojiye güvenmemesi ya da aynı aracı paylaştığı diğer kişilere güvenmemesi, otonom araçları güvenilir bulmasını zorlaştıracaktır (Gkartzonikas ve Gkritza, 2019). Paylaşımlı otonom araçlarda veya otonom toplu taşımalarında aynı aracı birden fazla kişi kullanacaktır. Kişi yabancılara karşı güvensizlik tutumu içerisindeyse bu araçları kullanmak istemeyecek ve özel araca yönelme eğilimi oluşacaktır.

Çevre ve altyapı faktörlerine baktığımızda, değişen durumlara otonom araçların uyum sağlaması kaygılara yol açabilmektedir. Otonom araçların hareket edebilmeleri için onlara özel şeritlerin ayrılmış olması ve araçların yol altyapısı ile sürekli iletişimde bulunması gerekmektedir. Araçların bu şeritlerde ve farklı trafik koşullarında nasıl performans göstereceği henüz bilinmemekte ve bu durum çeşitli kaygılara yol açmaktadır (Shabanpour ve diğ., 2018). Değişen hava koşulları, örneğin havanın çok sisli ya da çok karlı olması durumunda aracın ne şekilde davranacağı sorusu da kişilerde endişe uyandırmaktadır. 


\section{Otonom Araçlara İliş kin Kaza Analizleri}

Otonom araçların insana dair hataları ortadan kaldırıp trafik kazalarını azaltacağı düşünülmektedir. Yapılan çalışmalarda otonom araçların insan kaynaklı hataları \%94 oranında azaltacağı tespit edilmiştir (NHTSA, 2015). Her ne kadar otonom araçlara ait trafik kazaları sınırlı olsa da, bu kısımda rapor edilen sürücüsüz araçlara ait kazalar incelenecektir.

California Motorlu Taşıtlar Dairesinin (DMV) yayınladığı raporda otonom araçların yaptığı kazalar ve kazaların oluş şekillerine yer verilmiştir. Araçların test edilmeleri sırasında iki tane rapor oluşturulmuştur. Birinci rapor otonom araçlarla ilgili kazaları içerirken, ikinci rapor otonom araçların teknik ya da teknolojik bir bozukluk sonucu meydana gelebilecek aksaklıklarda gerektiğinde operatörün müdahale edeceği durumları içerir.

California Motorlu Taşıtlar Dairesi, 2014 yılından beri otonom araç kazaları ile ilgili 285 adet rapor yayınlamıştır. 2014 yılından 2021 yılına kadar yayınlanan raporlarda otonom araçların mil bazında seyahatlerinin artması ile gerçekleşen otonom araç kazaları arasında pozitif bir korelasyon olduğu görülmüştür. Yapılan analizler sonucu kazalara karşı verilen ortalama reaksiyon süresi 0.83 saniyedir (Dixit ve diğ., 2016).

Otonom araç ve geleneksel araçlara ait çarpışma türleri birbirinden farklılık göstermektedir. İki farklı araç çeşidiyle yapılan kaza türlerine ait oranlar Şekil $4 a$ ve Şekil $4 b$ 'de verilmiştir. Otonom araç kazalarının oluş şekilleri incelendiğinde en çok yapılan çarpışma türünün $\% 62$ oranında "arkadan çarpmalı kaza" olduğu görülmektedir. Bunlara ek olarak \%20'den fazla oranla "yandan çarpma", \%15 oranda "önden çarpma” kaza türlerinin meydana geldiğini sürücüsüz araçlar için söyleyebiliriz.

Geleneksel araçlarda kaza türleri otonom araçlara göre değişiklik göstermektedir. Geleneksel araçlarda en çok yapılan kaza türü \%45 oranında "önden çarpma" iken, bu oran otonom araçlardakinin üç katıdır. Bununla birlikte otonom araçlarda \%62 oranına sahip olan "arkadan çarpma" kaza türü, geleneksel araçlarda sadece \%4'tür. "Yandan çarpma" ve diğer faktörler, geleneksel araçlar için \%12 oranında kaza türleri arasında yer almaktadır.

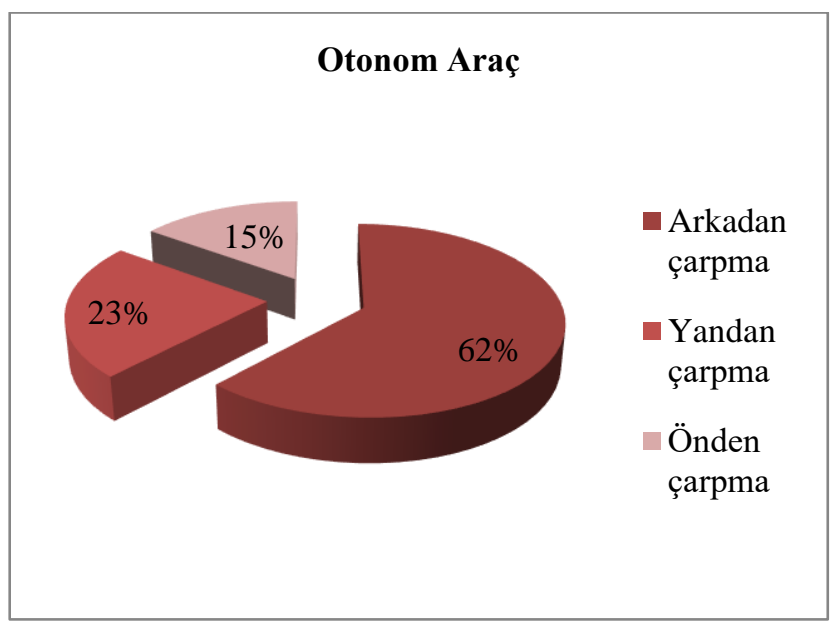

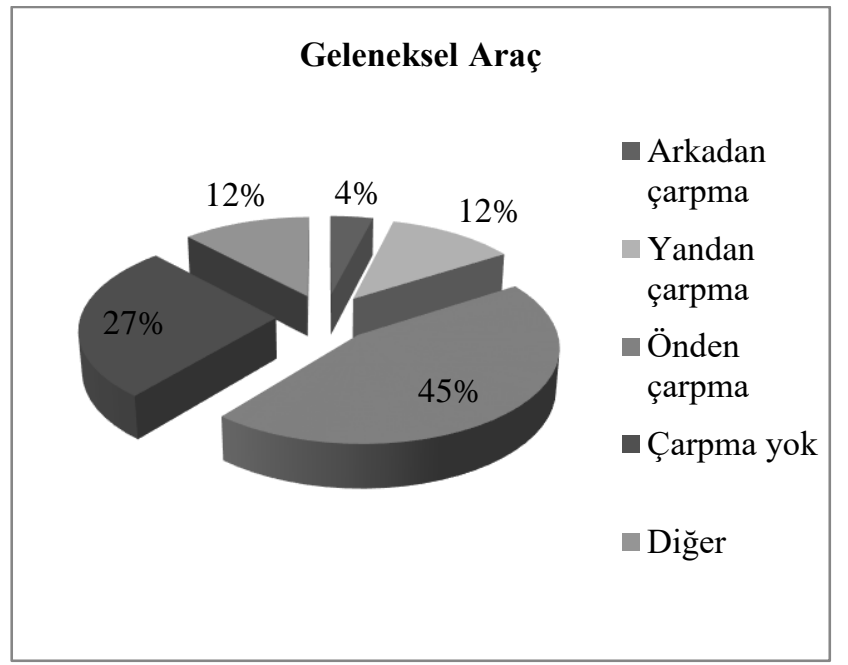

Şekil 4a.)Otonom araç b.) Geleneksel araç kaza türleri

Otonom araç kazaları çeşitli hız aralıklarında meydana gelmiştir. Şekil 5'te bu hız değerleri ve oranları gösterilmektedir. Yapılan incelemelere göre $10 \mathrm{mil} / \mathrm{saat}$ hızın altında kaza oranlarının artış gösterdiği tespit edilmiştir. Kazaların en çok 5 mil/saat ve $10 \mathrm{mil} / \mathrm{saat}$ hızları arasında meydana geldiği gözlemlenirken, 0-5 mil/saat hız aralıklarında \%28 oranında ikinci en çok kaza oranları ortaya çıkmaktadır. Hız 10 mil/saat'ten daha büyük bir değere çıktığında meydana gelen kaza oranları $10 \mathrm{mil} / \mathrm{saat}$ hız değerinde meydana gelen kaza oranından daha az olmaktadır. $15 \mathrm{mil} / \mathrm{saat}$ ile $20 \mathrm{mil} / \mathrm{saat}$ hızları arasında \%8 oranında kazalar meydana gelirken, geri kalan hız aralıklarında \%4'lük kazalar ortaya çıkmaktadır.

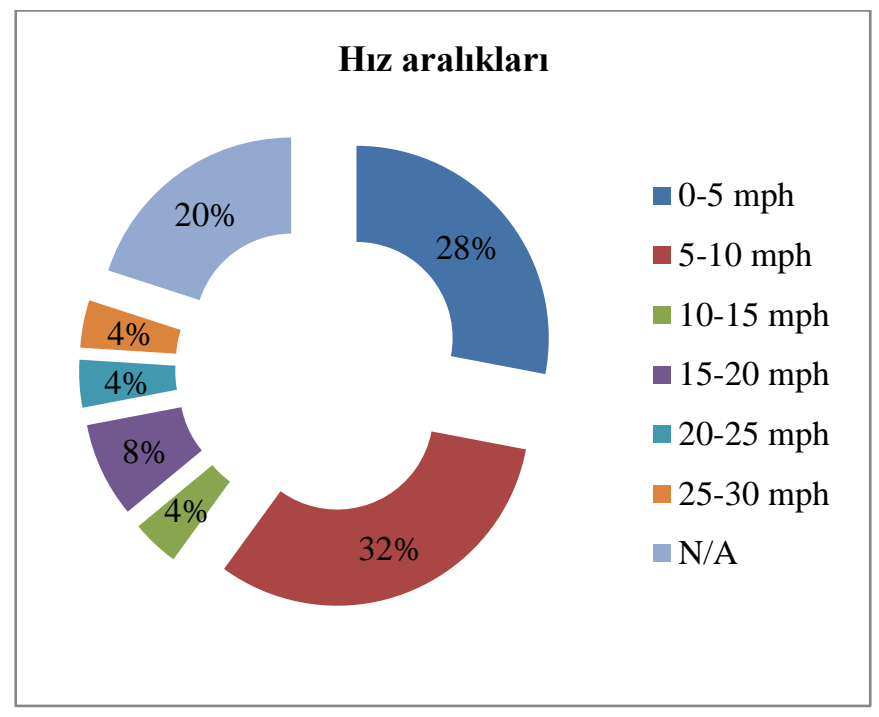

Şekil 5. Otonom araçların kazalarına ait hız aralıkları ve oranlart

Otonom araçlara ait kazaların nerelerde gerçekleştiği incelendiğinde \%89 oranında otonom araç kazalarının kavşaklarda meydana geldiği gözlemlenmiştir. Otonom araç kazaları \%48 oranında şehrin çevresindeki yerleşim alanlarında gerçekleşirken, \%32 oranında şehir merkezlerinde ve \%20 oranında otoyollarda meydana gelmektedir (Favarò ve diğ., 2017). 


\section{Sonuç}

$\mathrm{Bu}$ çalışma kapsamında otonom araçlar güvenlik ve benimsenmesi yönünden detaylı olarak incelenmiştir. Endüstrileşmiş birçok ülkede mevcut olan seviye "3" otonom araçlarının, 2022 yılında hemen hemen tüm araçlarda bulunacağ tahmin edilirken, 2030 y1lı itibari ile seviye "5" araçlarının ticarileştirilmesi beklenmektedir. Bu sebeple otonom araçların benimsenmesini etkileyecek faktörlerin incelenip, güvenlik açısından kaygıların ortaya çıkarılması, ortaya çıkabilecek tüm sorunlara çözüm önerileri getirilmesi bakımından önem taşımaktadır. Yapılan araştırmalar sonucunda otonom araçların kabullenilmesini etkileyen faktörler; psikolojik faktörler, güven faktörü ve çevresel faktörler olarak üç farklı gruba ayrılmıştır. $\mathrm{Bu}$ faktörleri oluşturan alt parametreler ayrıca incelenmiş olup, aralarındaki bağlantılar ortaya çıkarılmıştır. Otonom araçların benimsenmesi yönünde güvenlik faktörünün diğer faktörlerden daha çok öne çıkması, kişilerin güvenlik algılarının incelenmesi konusunu önemli kılmıştır. Kişilerin güvenlik kaygılarının detaylıca incelenmesi sonucunda otonom araçlara yapilabilecek siber saldırı riskleri, aracın yazılım ve donanımına saldırı ihtimalleri ve bilgi güvenliğinin korunamaması ile ilgili kaygılar en önemli etken olarak bulunmuştur. Bunlara ek olarak otonom araçlara ilişkin kaza analizleri incelenmiş olup, geleneksel araçlar ile karşılaştırmalar yapılmıştır. $\mathrm{Bu}$ analizler sonucunda otonom araçlarda en çok "arkadan çarpma" kaza türüleri meydana gelirken, geleneksel araçlarda "önden çarpma” kaza türleri meydana gelmektedir. Otonom araçlara ait bu kazalar en çok kavşak noktalarında meydana geliyorken, kaza esnasında araçlara ait hızların $5 \mathrm{mil} / \mathrm{saat}$ ve $10 \mathrm{mil} / \mathrm{saat}$ arasında değiştiği tespit edilmiştir.

$\mathrm{Bu}$ çalışmada ortaya çıkartılan otonom araçların benimsenmesine yönelik faktörler ve kişilerin bu araçlara karşı kaygıları; otonom araç üreticileri, karar vericiler ve politika yapıcılar için büyük önem taşımaktadır. Kaygıların giderilmesi için güçlü bir güvenlik yazılımı oluşturulmalı, bu yazılım şifrelenmeli ve siber saldırılara karşı aracı koruyabilmelidir. Bunun için yapay zekâ önemli bir anahtar olabilir; böylece aracın beklenmedik saldırılar karşısında nasıl davranacağı belirlenmiş olur. Bunlara ek olarak yapay zekâ kullanılarak aracın değişen çevre ve trafik koşullarında nasıl davranacağı konusu da çözüme kavuşmuş olacaktır. $\mathrm{Bu}$ çalışmanın devamında bu faktörler göz önünde bulundurularak anket çalışmaları yapılması ve kişilerin otonom araçlara karşı algılarının araştırılması önerilebilir. Çalışma sonucunda çıkan sonuçların ve önerilerin otonom araç ile ilgili tüm karar vericilere faydalı olması beklenmektedir.

\section{Kaynakça}

Bakioglu, G., \& Atahan, A. O. (2020). Evaluating the Influencing Factors on Adoption of Self-driving Vehicles by Using Interval-Valued Pythagorean Fuzzy AHP. In International Conference on Intelligent and Fuzzy Systems (pp. 503-511). Springer, Cham.

Bakioglu, G., \& Atahan, A. O. (2021). AHP integrated TOPSIS and VIKOR methods with Pythagorean fuzzy sets to prioritize risks in self-driving vehicles. Applied Soft Computing, 99, 106948.

Bansal, P., Kockelman, K.M. (2016). Forecasting Americans' long-term adoption of connected and autonomous vehicle technologies.
Begg, D. (2014). A 2050 vision for London: What are the implications of driverless transport, transport times, London, UK.

Brell, T., Philipsen, R., Ziefle, M. (2018). sCARy! Risk perceptions in autonomous driving: the influence of experience on perceived benefits and barriers. Risk Anal. 39 (2), 342-357. https://doi.org/10.1111/risa.13190.

Casley, S.V., Jardim, A.S., Quartulli, A.M., A. (2013). Study of public acceptance of autonomous cars, interactive qualifying project, Worcester Polytechnic Institute.

Chen D., Ahn S., Chitturi M., Noyce D.A. (2017). Towards vehicle automation: Roadway capacity formulation for traffic mixed with regular and automated vehicles, Transp. Res. Part B Methodol. 100, 196-221

Choi, J.K., Ji, Y.G. (2015). Investigating the importance of trust on adopting an autonomous vehicle. Int. J. Hum. Comput. Interact. 31 (10), 692-702.

Dixit VV, Chand S, Nair DJ. (2016). Autonomous vehicles: disengagements, accidents and reaction times. PLoS one, 11(12),

p.e0168054. https://doi.org/10.1371/journal.pone.0168054

Fagnant, D.J., Kockelman, K.,. (2015). Preparing a nation for autonomous vehicles: opportunities, barriers and policy recommendations. Transport. Res. Pol. Pract. 77, 167-181.

Favarò, F.M., Nader, N., Eurich, S.O., Tripp, M., Varadaraju, N. (2017). Examining accident reports involving autonomous vehicles in California.

Gkartzonikas C., Gkritza K. (2019). What have we learned? A review of stated preference and choice studies on autonomous vehicles. Transportation Research Part C, vol.98, 323-337.

Howard, D., Dai, D. (2014). Public perceptions of self-driving cars: the case of Berkeley, California. In: Paper Presented at the 93rd Annual Meeting of the Transportation Research Board, Washington D.C.

König, M. and L. Neumayr, (2017) Users' resistance towards radical innovations: The case of the self-driving car. Transportation Research Part F: Traffic Psychology and Behaviour. 44, 42-52.

Kyriakidis, M., Happee, R., De Winter, J.C.F. (2015). Public opinion on automated driving: Results of an international questionnaire among 5000 respondents. Transportation Res. Part F: Traffic Psychol. Behav. 32, 127-140.

NHTSA (2021). https://www.nhtsa.gov/technologyinnovation/automated-vehicles-safety

Noy, I. Y., Shinar, D., \& Horrey, W. J. (2018). Automated driving: Safety blind spots. Safety science, 102, 68-78.

Payre, W., Cestac, J., Delhomme, P. (2014). Intention to use a fully automated car: Attitudes and a priori acceptability. Transportation Res. Part F: Traffic Psychol. Behav. 27 (PB), 252-263.

Pettigrew, S., Dana, L. M., \& Norman, R. (2019). Clusters of potential autonomous vehicles users according to propensity to use individual versus shared vehicles. Transport Policy, $76,13-20$

Power, J.D. (2012). Vehicle owners show willingness to spend on automotive infotainment features, Technical Report, Westlake Village.

SAE International standard J3016: Taxonomy and Definitions for Terms Related to Driving Automation Systems for OnRoad Motor Vehicles J3016 (2018)

Sanbonmatsu, D.M., Strayer, D.L., Yu, Z., Biondi, F., Cooper, J.L. (2018). Cognitive underpinnings of beliefs and 
confidence in beliefs about fully automated vehicles. Transp. Res. Part F 55, 114-122.

Schoettle, B., Sivak, M.,. A. (2014). Survey of public opinion about connected vehicles in the U.S., the U.K., and Australia. 2014 International Conference on Connected Vehicles and Expo (ICCVE), Vienna, pp. 687-692

Shabanpour, R., Golshani, N., Shamshiripour, A., Mohammadian, A.K. (2018). Eliciting preferences for adoption of fully automated vehicles using best-worst analysis. Transportation Res. Part C: Emerging Technol. 93, 463-478.

Shin, J., Bhat, C. R., You, D., Garikapati, V. M., \& Pendyala, R. M. (2015). Consumer preferences and willingness to pay for advanced vehicle technology options and fuel types. Transportation Research Part C: Emerging Technologies, 60, $511-524$

World Health Organization. WHO Director-General's opening remarks at the media briefing on COVID-19. 2020. 